\title{
Reformasi Pertanian dan Pergeseran Solidaritas Sosial Weha Rima Masyarakat Petani Di Desa Sondosia Kabupaten Bima
}

\author{
Irmansah $^{1}$ dan Syukurman ${ }^{2}$ \\ Program Studi Pendidikan Sosiologi STKIP Bima \\ Jalan Piere Tendean Kel. Mande Tlp.Fax (0374) 42801, Bima 84191, Indonesia \\ email; irmansah92@yahoo.com \\ syukurmanstkip@gmail.com
}

\begin{abstract}
Abstrak
Masyarakat petani memiliki potensi modal sosial yang besar, baik berupa nilai dan institusi lokal yang akan menjadi sumber daya yang dapat menggerakkan perubahan secara konstruktif ditengah masyarakat. Modal sosial yakni "susah senang kita bersama" yang berarti bersama-sama dalam keadaan suka dan duka., itulah tradisi weha rima yang secara terminologinya memiliki sikap tolong menolong berupa pemberian tenaga tanpa mengharapkan imbalan materi namun harapannyadiberikan bantuan tenaga saat dibutuhkan, tetapi sayangnya tradisi weha rima telah mengalami pergerseran yang kian hari redup dimakan waktu, sekarang telah kehilangan ruh, spirit moral, dan makna. Penelitian ini mengungkap proses pergeseran solidaritas sosial weha rimapetani dengan tujuan mengetahui proses pergeseran solidaritas sosial weha rimapada masyarakat petani di Desa sondosia Kecematan Bolo Kabupaten Bima.Penelitian ini adalah penelitian deskriptif kualitatif dengan pendekatan studi kasus, penggalian data dengan cara wawancara mendalam. Penentuan subyekdengan teknik snowball sampling. pengumpulkan data dengan metode Desk study dan Field study, lalu pengujian keabsahan data dan kesimpulanAdapun hasil penelitian ini bahwa proses terjadinya pergeseran solidaritas weha rima diawali dengan industrialisasi alat-alat pertanian seperti masuknya traktor pembajak tanah yang sebelumnya menggunakan kerbau atau sapi, kemudian adanya alat mesin pemotong padi yang menyebabkan tenaga kerja yang dibutuhkan semakin berkurang,adanya pertisidadan pupuk mengurangi tenaga kerja dalam pembersihkan lahan pertanian, selain itu dipengaruhi juga oleh adanya sifat individualisme masyarakat sehingga weha rima diganti menjadi sistem upah. Hal inilah yang kemudian mempengaruhi pergeseran solidaritas weha rima masyarakat Desa Sondosia adalah semakin banyaknya masyarakat Desa Sondosia yang menempuh pendidikan tinggi dan berkerja disektor-sektor formal lainnya
\end{abstract}

Kata Kunci: Reformasi Sosial, Pergeseran Solidaritas, Weha Rima. 


\section{Pendahuluan}

Masyarakat petani memiliki potensi modal sosial yang besar, baik berupa nilai dan institusi lokal. Semestinya modal sosial itu bisa menjadi sumber daya yang bisa menggerakkan perubahan secara konstruktif di tengah kehidupan masyarakat. Sayangnya, potensi modal sosial itu gagal tergali dengan optimal dan tida dikelola menjadi sumber daya yang menggerakkan perubahan konstruktif di tengah masyarakat. Bentuk modal sosial pada masyarakat tercermin dari ungkapan masyarakat tempo dulu yakni "susah senang kita bersama" yang berarti bersama-sama dalam keadaan suka dan duka, yang diyakini sebagai wujud kepedulian antara sesamadalam menghadapi segala persoalan atau kesulitan hidup yang secara sadar menimbulkan perasaan kolektif. Selanjutnya, perasaan kolektif merupakan akibat (resultant) dari kebersamaan atau hasil aksi dan reaksi diantara kesadaran individual.Hal ini yang tercermin dalam masyarakat Bima tempo dulu yang nota bene mereka adalah masyarakat agraris, yang dimana mata pencariannya rata-rata petani penggarap sawah. Masyarakat tempo dulu selalu mengedepankan sikap kerja sama dalam menjalankan aktifitasnya dan selalu menjujung tinggi nilai solidaritas sosial sebagai refleksi terintegrasinya masyarakat petani

Salah satu dari modal sosial yang dimiliki masyarakat petani Desa Sondosia adalah tradisi weha rima. Weha rima dalam terminologi masyarakat Desa Sondosia diartikan sebagai sikap tolong menolong masyarakat tanpa mengharapkan imbalan dalam bentuk materi akan tetapi ada harapan agar orang yang dia bantu bisa membantunya ketika dia membutuhkan pertolongan dan itu melalui perjanjian. Tapi weha rima pada dunia pertanian merupakan sikap saling tolong menolong masyarakat melelui perjanjian antara satu dan yang lainnya untuk saling membantu. Contoh; ketika si A mau menanam padi maka si A mengajak tetangganya untuk weha rima, tetanggaya juga menyetujuinya karena tetangganya tersebut juga akan menanam padinya maka tetangganya tersebut ikut membantu si A akan tetapi si A juga harus membantu si tetangganya ketika tetangganya tersebut akan menanam padinya. Weharima di Desa Sondosia tempo dulu merupakan modal sosial yang lebih mencerminkan kuatnya sikap solidaritas sosial masyarakat. Tradisi weha rima sebagai properti cultural/modal budaya (cultural kapital) sangat menarik untuk kita cermati. Weha rima sebagai ekspresi solidaritas sosial dan kohesivitas masyarakat sudah sangat jarang ditemukan dalam kehidupan masyarakat petani Desa Sondosia akhir-akhir ini. Weha rima pada masa lalu merupakan aktifitas sosial masyarakat, dan bahkan weha rima tidak hanya berlaku dalam kegiatan pertanian saja, akan tetapi juga pada acara-acara kematian dan pesta 
Reformasi Pertanian dan Pergeseran Solidaritas Sosial Weha Rima

Weha rima ini sebenarnya

mencerminkan sikap gotong royong masyarakat petani dalam mengelola sawahnya. Weha rima merupakan bentuk saling tolong menolong yang berlaku dalam masyarakat Desa Sondosia tapi sekarang terjadi pergeseran bahkan akan semakin memudar dan tidak dilaksanakan lagi. Pada hal kalau kita perhatikan bersama Tradisi weha rima merupakan aset atau modal (capital) sosial yang telah diakui perannya dalam merubah pola hidup masyarakat kearah yang lebih baik. Karena dipercaya bahwa kekuatan selemah apapun ketika disinergikan menjadi milik bersama maka dipercaya sangat bermanfaat bagi kemampuan membangun jaringan sosial (sosial network) untuk kesuksesan secara umum. Dan sebenarnya manivestasi dari kuatnya solidaritas sosial tercermin dalam tradisi weha rima, sederhananya, semua persoalan akan lebih mudah kalau dikerjakan secara bersama-sama, sepersti pribahsa yang bilang "berat sama dipikul, ringan sama dijinjing".

Weha rima di Desa Sondosia tumbuh dan berkembang sejak dahulu kala. Di dalamnya terdapat semangat solidaritas dan kohesifitas yang menjadi spirit utama aktivitas weha rima. Weha rimaadalah bentuk aktif dari semangat yang bersifat spontan, kolektif dan berlandaskan sikap membantu atau menolong sesama dengan sukarela, senang hati dan ikhlas. Prinsip dasar yang menggerakkan weha rimaadalah keyakinan hidup memerlukan interaksi dan berbagi dengan sesama. Semangat weha rimainilah yang merupakan modal sosial dalam membangun ikatan sosial yang kuat. Weha rima bisa dimaknai sebagai upaya kreatif, sistematis dan berkelanjutan untuk memperkuat modal sosial yang ada di dalam masyarakat. Memperkuat di sini bisa bermakna memberi roh atau spirit baru. Bisa pula berarti mengembangkan roh atau spirit yang sudah ada. Sederhananya, menjadikan spirit weha rima untuk memperkuat solidaritas sosial dan ikatan sosial yang melahirkan energi sosial yang besar dan spontan, bisa terkelola untuk hal- hal yang produktif, tetapi sayangnya tradisi tersebut gagal terlaksana dengan optimal. Weharima menjadi istilah yang kian hari kian redup dimakan waktu. Istilah tersebut telah kehilangan ruh, spirit moral, dan kehilangan makna. Padahal istilah tersebut mengandung spirit persatuan dan solidaritas yang sejati. Weha rima (dulunya) menjadi kegiatan yang menunjuk pada persatuan ruh dan kesadaran masyarakat. Maka paling yang mendasar (elementer) dari konsep weha rima yaitu citra hidup guyub dan citra kesatuan masyarakat. Konsep tersebut secara praksis diperlihatkan oleh pertalian emosional masyarakat.

\section{Tinjauan Pustaka}

\section{A. Pergeseran Solidaritas Sosial}

\section{Pengertian Pergeseran}


Kata pergeseran sebenarnya menunjukkan sesuatu perubahan dari keadaan yang sebenarnya, maka kata pergeseran ini sama dengan kata perubahan. Karena perubahan juga berarti suatu peroses yang mengakibatkan keadaan sekarang berbeda dengan keadaan yang sebelumnya. Disamping itu juga dalam ilmu sosiologi ada yang secara khusus mempelajari tentang perubahan sosial maka ada baiknya kita memahami kata pergeseran tersebut melalui kajian perubahan sosial. Telah cukup banyak para ahli sosiologi yang membicarakan dan memperdebatkan istilah perubahan masyarakat, akan tetapi masih belum ditemukan definisi yang memuaskan, bahkan masih sering terjadi pertentangan dan perbedaan pendapat. Agar tidak menimbulkan kekaburan dan kesimpangsiuran dalam pengertiannya, maka perlu pembatasan terhadap ruang lingkup perubahan masyarakat. Ruang lingkup perubahan masyarakat itu terdiri dari unsur-unsur kebudayaan, baik yang bersifat immaterial maupun yang bersifat material. Perubahan masyarakat secara umum menyangkut perubahan-perubahan struktur, fungsi budaya dan prilaku masyarakat.

Menurut Kingsly Davis perubahan sosial diartikan sebagai perubahanperubahan sosial yang terjadi dalam struktur dan fungsi masyarakat. Misalnya, lemahnya sikap gotong royong masyarakat karena timbulnya sikap individualis masyarakat akibat masuknya sistim kapitalisme pada masyarakat. Sedangkan Gillin dan Gillin mengatakan perubahanperubahan sosial sebagai suatu variasi dari cara-cara hidup yang telah diterima, baik karena perubahan-perubahan kondisi geografis, kebudayaan material, komposisi penduduk, ideology, maupun karena adanya penemuan-penemuan baru dalam masyarakat. Secara singkat Samuel Koenig mengatakan bahwa perubahan sosial menunjuk pada modifikasi-modifikasi yang terjadi dalam pola-pola kehidupan manusia. Modifikasi-modifikasi terjadi karena sebab-sebab internal maupun sebab-sebab eksternal (Seorjono Soekanto, 2006: 304).

Dengan demikian dapat disimpukan bahwa proses pergeseran masyarakat pada dasarnya merupakan perubahan pola prilaku kehidupan dari seluruh norma-norma sosial yang lama menjadi pola prilaku yang baru dan seluruh norma-norma sosial secara seimbang, berkemajuan dan berkesinambungan. Polapola kehidupan masyarakat lama yang dianggap sudah asing diganti dengan polapola kehidupan baru yang lebih dianggap sesuai dengan kebutuhan sekarang dan masa mendatang. 


\section{Solidaritas Sosial}

Dalam kamus ilmiah popular solidaritas sosial berarti; rasa kesetiakawanan atau rasa sepenanggung jawab (Tim Prima Pena, 2006: 443). Jadi solidaritas merupakan sikap kebersamaan yang terbangun melalui intraksi yang terjalin dalam sebuah individu atau kelompok dengan individu atau kelomopk lainnya, yang menunjuk pada satu keadaan hubungan yang didasarkan pada perasaan moral dan kepercayaan yang dianut bersama yang diperkuat oleh pengalaman emosional bersama. Ikatan ini lebih mendasar dari pada hubungan kontraktual yang dibuat atas persetujuan rasional, karena hubungan-hubungan serupa ini mengandaikan sekurang-kurangnya satu tingkat/derajat konsensus terhadap prinsipprinsip moral yang menjadi dasar kontrak itu. Pokok ini sering dikemukakan Durkheim dalam serangannya yang terusmenerus terhadap Sepencer, Rousseau, dan lain-lainnya yang berusaha menjelaskan asal keadaan menurut persetujuan kontraktual yang dirembuk individu untuk kepentingan pribadi mereka.

\begin{tabular}{lcr}
\multicolumn{2}{c}{ Konsep $\quad$ solidaritas } & sosial \\
merupakan konsep sentral & Emile \\
Durkheim $\quad(1858-1917)$ & dalam \\
mengembangkan $\quad$ teori & sosiologi.
\end{tabular}

Durkheim (Jhonson, 1994:181) menyatakan bahwa solidaritas sosial merupakan suatu keadaan hubungan antara individu atau kelompok yang didasarkan pada perasaan moral dan kepercayaan yang dianut bersama dan diperkuat oleh pengalaman emosional bersama. Solidaritas sosial menekankan pada keadaan hubungan antar individu dan kelompok dan mendasari keterikatan bersama dalam kehidupan dengan didukung nilai-nilai moral dan kepercayaan yang hidup dalam masyarakat. Wujud nyata dari hubungan bersama akan melahirkan pengalaman emosional, sehingga memperkuat hubungan antar mereka.Berkaitan dengan perkembangan masyarakat, Durkheim melihat bahwa masyarakat berkembang dari masyarakat sederhana menuju masyarakat modern. Salah satu komponen utama masyarakat yang menjadi pusat perhatian Durkheim dalam memperhatikan perkembangan masyarakat adalah bentuk solidaritas sosialnya. Masyarakat sederhana memiliki bentuk solidaritas sosial yang berbeda dengan bentuk solidaritas sosial pada masyarakat modern. Masyarakat sederhana mengembangkan bentuk solidaritas sosial mekanik, sedangkan masyarakat modern mengembangkan bentuk solidaritas sosial organik.

Menurut Durkheim, berdasarkan hasilnya, solidaritas sosial dapat dibedakan 
antara solidaritas mekanik dan soidaritas organik.

a. Solidaritas sosial mekanik

1) Pengertian solidaritas sosial mekanik

Solidaritas sosial mekanik adalah masyarakat atau kelompok sosial yang didasarkan pada kesadaran kolektif, kebersamaan. Ikatan dalam solidaritas sosial mekanik terjadi karena kesamaan aktivitas dan merasa memiliki tanggung jawab yang sama, sehingga ikatannya sangat erat. Solidaritas sosial mekanik dibentuk oleh hukum represif. Hukum represif sendiri adalah hukum yang sifatnya mendatangkan penderitaan pada pelanggar. Sanksi nya sendiri bisa berupa perampasan kemerdekaan pada hidupnya.hal ini disebabkan karena dalam solidaritas mekanik, pelanggaran dianggap sebagai pencemaran pada kepercayaan bersama. Dalam masyarakat solidaritas sosail mekanik, individualitas tidak berkembang karena yang diutamakan adalah kepentingan bersama. Solidaritas sosial mekanik adalah masyarakat sederhana yang hidup terpisah dalam kelompok-kelompok kecil.
Pada masyarakat ini belum ada pembagian kerja atau spesialisasi dalam hal pekerjaan karena pada dasarnya setiap pekerjaan dilakukan secara bersama-sama atau gotong royong. Masyarakat ini juga terikat oleh kesamaan dan kesadaran bersama yang kuat. Hubungan sosial yang terjadi di antara anggota masyarakat cenderung akrab dan didasarkan pada sistem nilai yang sama.

2) Ciri-ciri solidaritas sosial mekanik Ciri solidaritas sosial mekanik adalah solidaritas yang merujuk kepada ikatan sosial yang dibangun atas kesamaan, kepercayaan dan adat bersama. karena orang yang hidup dalam unit keluarga suku atau kota relatif dapat berdiri sendiri dan juga memenuhi semua kebutuhan hidup tanpa tergantung pada kelompokkelompok lain.

3) Contoh solidaritas sosial mekanik Contoh solidaritas sosial mekanik adalah masyarakat pedesaan yang masih tradisional. Pada umumnya masyarakat tersebut mempunyai pekerjaan yang sama, yaitu sebagai petani.

b. Solidaritas Sosial Organik. 
1) Pengertian solidaritas sosial organik

Solidaritas sosial organic adalah masyarakat yang didasarkan pada ketergantungan antar individu dan adanya spesialisasi pekerjaan. Dalam solidaritas sosial organik motivasinya biasanya karena ada faktor ekonomi seperti misalkan karena ia memiliki peran dalam sebuah kelompok atau masyarakat ia menginginkan gaji atau setidaknya balas jasa. Jadi dalam kegiatannya selalu berhubungan dengan faktor ekonomi. Dengan demikian muncul keahlian tertentu yang dimiliki oleh setiap anggota masyarakat yang mengakibatkan setiap golongan dalam masyarakat saling tergantung satu sama lain dan tidak dapat hidup secara sendiri tanpa melakukan hubungan atau kerja sama dengan golongan lain dalam masyarakat. Namun demikian kesadaran bersama di antara mereka sangat lemah

2) Ciri-ciri solidaritas sosial organik

Ciri solidaritas sosial organic adalah menguraikan tatanan sosial berdasarkan perbedaan individual diantara rakyat, yang merupakan ciri dari masyarakat modern, khususnya yaitu daerah perkotaan. Bersandar pada pembagian kerja yang rumit dan didalamnya orang terspesialisasi dalam pekerjaan yang berbeda-beda. Dalam pembagian kerja yang rumit ini, Emile Durkheim melihat adanya kebebasan yang lebih besar untuk semua masyarakat

3) Contoh solidaritas sosial

Organik ini dapat dilihat pada masyarakat perkotaan yang lebih modern dan kompleks. Yaitu masyarakat yang ditandai dengan adanya pembagian kerja yang kompleks, masalah sentral dalam analisa sosiologi adalah menjelaskan keteraturan sosial yang mendasar yang berhubungan dengan proses-proses sosial yang meningkatkan integritas dan solidaritas sosial dalam upaya meningkatkan komitmen terhadap tujuan dan kegiatan kelompok, moral kelompok, dan mengatasi konflik. Anggota-anggota kelompok berbeda dalam hal besarnya kesadaran akan masalah-masalah itu,dan seberapa jauh mereka menyusun strategi untuk meningkatkan solidaritas sosial tersebut. Inilah masalah utama bagi Durkheim, dan juga salah satu masalah 
pokok dalam persfektif fungsional masa kini, khususnya yang diwakili oleh Parsons dan pengikutpengikutnya.

Talcot Parsons adalah seorang sosiolog kontemporer dari Amerika yang menggunakan pendekatan fungsional dalam melihat masyarakat, baik yang menyangkut fungsi dan prosesnya. Pendekatannya selain diwarnai oleh adanya keteraturan masyarakat yang ada di Amerika juga dipengaruhi oleh pemikiran Auguste Comte, Emile Durkheim, Vilfredo Pareto dan Max Weber. Hal tersebut di ataslah yang menyebabkan Teori Fungsionalisme Talcott Parsons bersifat kompleks (Jhonson, 1990:103).

Asumsi dasar dari Teori Fungsionalisme Struktural, yaitu bahwa masyarakat terintegrasi atas dasar kesepakatan dari para anggotanya akan nilai-nilai kemasyarakatan tertentu yang mempunyai kemampuan mengatasi perbedaan-perbedaan sehingga masyarakat tersebut dipandang sebagai suatu sistem yang secara fungsional terintegrasi dalam suatu keseimbangan. Dengan demikian masyarakat adalah merupakan kumpulan sistem-sistem sosial yang satu sama lain berhubungan dan saling ketergantungan.Masalah integrasi menunjuk pada kebutuhan untuk menjamin bahwa ikatan emosional yang cukup yang menghasilkan solidaritas sosial dan kerelaan untuk bekerja sama dikembangkan dan dipertahankan. Ikatan-ikatan emosional ini tidak boleh tergantung pada keuntungan yang diterima atau sumbangan yang diberikan untuk tercapainya tujuan individu atau kolektif. Kalau tidak, solidaritas sosial dan kesediaan untuk kerja sama akan jauh lebih goyah sifatnya, karena hanya didasarkan pada kepentingan diri pribadi semata-mata (Jhonson, 1990:130).

\section{Teori Solidaritas Sosial}

Dalam teorinya Emile Durkheim tentang perubahan solidaritas sosial masyarakat, dari solidaritas sosial mekanik ke solidaritas organik. Yang dimana solidaritassosial mekanik merupakan solidaritas sosial yang terbangun atas dasar kesadaran kolektif yang kuat dalam masyarakat dan memiliki keterikatan bersama sehingga mereka terlibat dalm aktivitas yang sama dan memiliki tanggung jawab yang sama. Solidaritas sosial mekanik ini membahas masyarakat primitif yang dimana masyarakat primitif ini memiliki kesadaran kolektif yang lebih kuat, yaitu pemahaman, norma dan 
kepercayaan bersama, sementara itu ketika masyarakat semakin kompleks melalui pembagian kerja, solidaritas sosial mekanik runtuh digantikan dengan solidaritas sosial organik

Solidaritas organik adalah hubungan masyarakat yang dilandaskan pada asas untung dan rugi serta lebih cenderung kearah individualistis karena tingkat kesadaranya masih rendah, yang dimana solidatitas sosial oerganik ini ada pada masyarakat moderen (George, 2012:90-93)

\section{B. Masyarakat Petani}

\section{Pengertian Masyarakat Petani}

Dalam kamus bahasa Indonesia, kata petani berarti orang yang bercocok tanam, bertani. Jadi, petani adalah seseorang yang memiliki lahan pertanian dan mengelola lahannya sebagai mata pencariannya dalam memenuhi kebutuhan sehari-harinya. Petani memiliki klasifikasi, diantaranya. Pertama; petani gurem adalah petani kecil yang memiliki luas lahan adalah 0,25 ha. Petani ini merupakan kelompok petani miskin yang memiliki sumber daya terbatas. Kedua; petani modern merupakan kelopok petani yang menggunakan teknologi dan memiliki orientasi keuntungan melalui pemanfaatan teknologi tersebut. Apabila petani tersebut memiliki lahan 0,25 ha tapi pemanfaatan teknologinya baik dapat juga dikatakan petani modern. Ketiga; petani primitive adalah kelompok petani dahulu yang bergantung pada sumber daya dan kehidupan mereka berpindah-pindah (nomaden).

Keberadaan tanah bagi petani, selain bernilai ekonomis, sebagai sumber kehidupan, juga bermakna magis religiokosmis dan bahkan ideologis. Ironisnya sejak zaman colonial, bahkan jauh sebelumnya yakni dimasa kerajaan, hingga kini sejarah pertanahan (yang identik dengan nasib kehidupan petani itu) tidak banyak menunjukkan adanya tanda-tanda perbaikan. Kehidupan petani selalu terombang-ambing oleh ketidakpastian akibat kebijakan Negara tentang pertanahan yang sering berubah-ubah.

Di zaman kerajaan, petani hanya mempunyai hak garap atas tanah setelah mendapat izin dari Bekel. Ketika inggris menjajah Indonesia (1811-1816), legalitas agraris diatur melalui Domain Theory. Setelah Van dan Bosch memegang kendali pemerintahan, selain dia keluarkan kebijakan system tanam paksa, Cultuurstelsel (1830-1870), para petani juga diwajibkan untuk ikut membangun proyek-proyek besar (waduk, jalan raya, dan kereta api) dan bekerja di perkebunan, terutama diperkebunan tebu. Kebijakan ini kemudian digantikan oleh Agrarische Wet 
dengan menrepkan Agrarische Beslut (staatsblad no. 118/1870) yang menerapkan asas domain verklaring, suatu prinsip yang menyatakan semua tanah yang tidak ada bukti kepemilikan atas tanah adalah domeidn Negara. Setelah itu, dikeluarkanlah undang-undang agraris 1870 yang mengakomodasikan swasta belanda berbisnis di Indonesia. Meski politik etis termasuk mengoreksi prilaku bisnis swasta belanda yang ekspoitatif terhadap petani, kenyataannya prilaku bisnis swasta colonial tetap mengedepankan kepentingan perkebunannya dan, lebih dari itu, selalu berusaha memperoleh kepastian menjangkau penyediaan tanah dalam waktu yang panjang.

Mengingat struktur kepemilikan dan penguasaan tanah masih timpang, maka setelah Indonesia merdeka (19451965) presiden soekarno membuat kebijakan untuk penataan agrarian. Suatu kebijakan yang dikenal sangat populis dan nasionalis. Asumsinya, penataran kepemilikan dan/atau penguasaan agraria perlu dilakukan sebelum dilakukan industrialisasi. Selama pemerintahan soekarno, rakyat mulai merasakan kebebasan, namun yang kelihatan paling siap merespons kebijakan land reform itu adalah Partai Komunis Indonesia (PKI), meski akhirnya gagal.
Nasib petani di pedesaan semakin terpuruk ketika ideology devlomentalism menjadi pilihan paradigma pembangunan rezim Orde Baru (yang ironisnya konsep ini bukan sepenuhnya produk elite Negara, melainkan hasil konstruksi kekuatan capital global) yang kenyataannya sangat problematik bagi petani, dengan ditopang investasi modal asing secara besar-besaran melalui industrialisasi yang untuk keperluan oprasionanya sangat membutuhkan ketersedian tanah. Akibatnya, tanah menjadi komoditas dan memunculkan pasar tanah, sehingga investor lebih tertarik menanamkan modalnya dalam bentuk tanah karena sangat menguntungkan. Proses ini tanpa disadari telah mengintegrasikan petani dengan tanahnya ke dalam system kapitalisme melalui ekspresi pasar dengan fasilitas intervensi kebijakan Negara.

Teori rasional berasumsi setiap manusia pada dasarnya rasional dengan selalu mempertimbangkan prinsif efisiensi dan efektivitas dalam melakukan setiap tindakan. Dengan tetap mengakui adanya determinan factor seperti solidaritas masyarakat petani, substansi perekonomian petani dan hubungan produksi masyarakat prakapitalis, namun pengaruh rasionalitas slalu dalam konteks beroprasinya mekanisme kepentingan rasional individu anggota komunitis. 
Alfred Marshall (1842-1924) menyatakan

bahwa manusia selalu cenderung memaksimalkan rasionalitasnya, selalu berusaha menghitung nilai sesuatu (utility) yang hendak dipetukarkan. Selain itu juga popkin, dalam bukunya The Rational Peasant: The Political Economy Of Rural Society In Vietnam, (1979) menyebutkan bahwa semua perlawanan petani tidaklah dimaksudkan untuk menentang program Negara, dalam hal ini revolusi hijau, tetapi lebih dimaksudkan untuk menentang kekuasaan elit desa (petani kaya), yang selama ini mengklaim mewakili komunitas tradisional; padahal lebih untuk mempertahankan tatanan yang lebih menguntungkan mereka (Mustain, 2007: $35)$.

Bagi popkin, petani adalah manusia-manusia rasional, kreatif dan juga ingin menjadi orang kaya. Kesempatan itu terbuka untuk petani dan, menurutnya, akan bisa didapatkan seandainya petani memiliki akses yang lebih leluasa dengan pasar. Namun, persoalannya, petani tidak mempunyai kesempatan sehingga tidak dapat menjual hasil pertaniannya sendiri kepasar. Mereka mengkalkulasi prospek kembalinya investasi dan kualitas organisasi dimana mereka memberikan kontribusinya. Bagi popkin, campur tangan organisasi politik diluar petani merupakan pendorong timbulnya kesadaran petani untuk menjadi political entrepreneur melalui kekuatan solidaritas dan kohesifitas yang sudah dibangun.

\section{Masyarakat Petani Berdasarkan} Kelas-Kelasnya

Masyarakat petani adalah masyarakat yang tinggal di Desa, yang secara wilayahnya berbeda dengan kota dan ciri geografisnya atau ekologis memiliki karakter yang unik. Menurut Wolf, 1983 (Husain Assadi, 2008) bahwa masyarakat petani merupakan fase setelah masyarakat primitif dan masyarakat modern. Pendekatan antropologis yang ia bangun didasarkan atas bahwa masyarakat petani tidak bisa hanya dipandang sebagai agregat tanpa bentuk. Masyarakat petani memiliki keteraturan dan memiliki bentukbentuk organisasi yang khas.

Menurut Dawan Rahardjo, 1986 (Husain Assadi, 2008) kelas-kelas petani yang ada dalam masyarakat pedesan ada beberapa tingkat, yaitu:

a. Tuan tanah, yaitu petani yang memiliki lahan pertanian lebih dari 5,0 ha. Sebagian dari mereka mampu menggarap lahan dengan tenaga kerja keluarga atau dengan mempekerjakan beberapa buruh tani. Sebagian pula menyewakan (menyewakan dengan system bagi hasil) seluruh atau sebagian lahan itu kepada petani penggarap. 
b. Petani kaya, yaitu petani yang memliki lahan antar 2,0 sampai 5 ha. Petani semacam ini ada kalanya juga menyewakan kepada orang lain karena tidak mampu menggarap semua lahan yang dimilikinya

c. Petani sedang, yaitu petani yang memiliki lahan pertanian antara 0,5 ha sampai 2,0 ha.

d. Petani kecil, yaitu mereka yang memiliki lahan pertanian antara 0,25 ha sampai 0,5 ha

e. Petani gurem, yaitu petani yang hanya memiliki lahan pertanian antara 0,10 sampai 0,25 ha

f. Buruh tani, yaitu petani yang hanya memiliki lahan kurang dari 0,10 ha. Bahkan petani ini juga dapat digolongkan pada mereka yang tidak mempunyai lahan sama sekali.

Menurut Sajogya dan Pudjiwati Sajogya, 1990 (Husain Assadi, 2008), masyarakat desa atau petani dibagi dua kelompok, yaitu;

a. Buruh tani

$$
\text { Buruh tani merupakan }
$$
golongan yang mempunyai posisi paling rendah, karena buruh tani tidak memiliki lahan sama sekali. Mereka hanya bermodal tenaga untuk mendapatkan pekerjaan guna memperoleh sesuatu demi kelangsungan hidupnya. Biasanya mereka hidup dalam keadaan yang miskin. Buruh tani berada ditingkat terendah dalam lapisan masyarakat. Mereka tidak mungkin jatuh lebih rendah lagi.

b. Petani bebas

Menurut Sajogya dan Pudjiwati Sajogya, 1990 (Husain Assadi, 2008), Petani bebas ini dapat dibedakan menjadi dua kelompok, yaitu:

(1) Petani bebas kecil yakni pada umumnya mereka mengerjakan tanah sendiri atau terkadang mengerjakan sawah dasar bagi hasil. Mereka tidak melakukan pekerjaan untuk mencari upah.

(2) Tuan tanah besar yakni mereka hanya menjalankan fungsi sebagai pengelola, sehingga mereka jarang sekali mengerjakan sendiri pekerjaan kasar. Masalah perolehan pinjaman mereka dapat meminjam dengan melalui Dinas Pertanian.

Setiyono Wahyudi, 2006 (Husain Assadi, 2008), ada tiga macam kebiasaan mental petani yang penting bagi perkembangan pembangunan pertanian yaitu :

a. Kebiasaan mengukur, yaitu berpikir dalam mengukur penggunaan sarana produksi yang akan dipergunakan 
termasuk jumlah benda-benda. Dengan

kebiasaan itu jangan puas dengan menyatakan panen baik atau hasil cukup, tetapi seharusnya dalam jumlah ton atau kilogram per hektar.

b. Kebiasaan bertanya, biasanya dilakukan dengan pertanyaan, "mengapa tanaman ini lebih baik dari tanaman itu?" kenapa hasil di sini lebih buruk dari hasil yang disana"?

c. Kebiasaan melihat atau mencari alternatif. Melihat dan mencari alternatif dari cara yang sudah dikenal dan dilakukan terhadap cara baru yang lebih baik

Soerjono Soekanto yang dikaji oleh Mardiyati (2002 : 13) menemukan ciri-ciri kehidupan petani, yaitu sebagai berikut :

(1) Masih ada hubungan saling mengenal dan bergaul antar warga

(2) Secara umum hidup dari hasil pertanian.

(3) Berusaha mempertahankan tradisi yang sudah ada, sehingga orangtua pada umumnya memegang pedoman yang sangat penting.

(4) Tidak dijumpai adanya pembagian kerja berdasarkan keahlian, akan tetapi berdasarkan usia dan jenis kelamin.

(5) Kehidupan penduduk pedesaan sangat terikat oleh tanah, maka kepentingan pokoknya juga sama sehingga akan terjalin hubungan kerja sama (gotongroyong).

\section{Makna Weha Rima Bagi Masyarakat Petani}

\section{Pengertian Weha Rima}

Kata weha rima merupakan bentuk aktif dari kata saling bantu/saling tolong menolong yang dilandasi oleh spirit dan pemahaman bahwa kehidupan memerlukan intraksi dan berbagi dengan sesama. Sebagai salah satu produk kearifan local, weha rima merupakan manivestasi dari kuatnya solidaritas sosial atau persatuan masyarakat di Desa Sondosia. Dalam terminologi masyarakat Desa Sondosia, weha rima dipahami sebagai "persekutuan komunitas terkecil yang eksistensinya berada pada setiap gubug atau kampung," dimana di -dalam weha rimaitu, secara spontan berlangsung pada kegiatan sosial kemasyarakatanwarga Desa Sondosia.

Dan selain hal itu juga weha rima merupakan aset atau modal (capital) sosial yang telah diakui peranannya dalam merubah pola hidup masyarakat kearah yang lebih kohesif. Bourdieu (1985) merupakan pencetus teori sosial capital dalam konsep habitusnya dan telah banyak dikembangkan mendekati fenomena pembangunan sosial, sperti; meninggkatkan partisipasi masyarakat, meningkatkan income dan tingkat hidup 
ekonomi masyarakat, termasuk membangkitkan partisipasi masyarakat dalam pembangunan baik dalam konteks makro maupun mikro. Pada dasarnya teori sosial kapital dimunculkan untuk membangun hubungan antar manusia dalam mensukseskan kebutuhan kolektif. Karena dipercaya bahwa kekuatan selemah apapun ketika disinergikan menjadi milik bersama maka dipercaya sangat bermanfaat bagi kemampuan membangun jaringan sosial (sosial network) untuk kesuksesan secara umum (Mahyuni: 2009: 19).

Oleh karenanya, weha rima sebagai property kultural (cultural capital) sangat menarik untuk dicermati. Weha rima sebagai ekspresi solidaritas sosial dan kohesivitas masyarakat sudah sangat jarang ditemukan dalam kehidupan seharihari masyarakat. Dalam konteks komunal, tradisi weha rima juga diklaim sangat efektif dalam upaya pembangunan desa.

\section{Persyaratan Weha Rima}

Budaya weha rima bagi masyarakat Bima telah dilakukan sepanjang kehidupan masyarakat petani secara turun temurun sampai sekarang walaupun ada beberapa aspek yang mengalami perubahan. Kesepakatan weha rima dilakukan dengan tenaga dan tidak bisa tergantikan oleh uang ataupun yang lainnya dan hanya dibayar dengan tenaga berdasarkan pelaksanaan kgiatan tani sesuai waktu yang ditentukan. Pelaksanaan weha rima adalah pelaksanakan yang dilakukan dengan cara kesiapan tenaga dan dibayar dengan tenaga, kemudian dilaksanakan dengan cara bersama-sama dan bergiliran sampai selesai pelaksanan kegiatan pertanian berlangsung, apabila salah satu diantara mereka berhalangan, maka wajiblah bagi mereka untuk mencari tenaga lain menggantikannya. Persayaratan weha rima ini dapat pula di sebut janji yang sangat ditakuti oleh petani dalam hal pelanggaran, karena pelanggaran dalam istilah weha rima akan mendapatkan penyimpangan nilai dan budaya yang dalam kehidupannya mendapatkan sanksi seperti a) krisis kepercayaan dari petani lainnya, b) pelanggaran akan mengalami rasa malu yang berkepanjangan, c) sangat jarang lagi dilibatkan dalam pelaksanaan weha rima berikutnya serta dan dapat menimbulkan sifat-sifat individualism atau tidak saling kerjasama.

\section{Metode Penelitian}

Penelitian ini menggunakan metode kualitatif dengan pendekatan studi kasus (case study)sebagaimana Bungin $(2008 ; 68)$ menyatakan bahwa penelitian kualitatif merupakan penelitian yang bersifat studi kasus. Penentuan informan dilakukan dengan 
cara snowball sampling, diawali dengan menghubungi Kepala Desadan ketua kelompok tani. Berdasarkan rekomendasi mereka, pencarian akan dilanjutkan pada level masyarakat petani secara detil, begitu seterusnya hingga data yang dikumpulkan mencapai titik jenuh.Metode pengumpulan data digunakan untuk memecahkan dan menganalisis masalah yang telah dirumuskan sebelumnya, yakni:Desk studydan Field study: sedangkan teknik analisis data yang digunakan berupa (a) Proses pengumpulan data: peneliti mengumpulkan data-data yang diperoleh dari berbagai sumber, baik itu dari sumber primer maupun sekunder yang berkaitan dengan penelitian ini; (b) Reduksi data: data yang telah diperoleh di lapangan disortir dan dikurangi untuk diambil data-data penting saja yang berkaitan dengan penelitian ini; (c) Penyajian data sekaligus tahap verifikasi: data-data penting yang telah diambil kemudian ditelaah, dicek ulang, dan disajikan sebagai langkah pembahasan terhadap permasalahan penelitian; dan (d) Pengambilan kesimpulan: peneliti mengambil data yang paling penting yang telah disajikan dalam pembahasan permasalahan penelitian ini.

\section{Hasil Penelitian}

Weha rima dimaknai sistem tolong menolong atau membantu salah satu warganya yang mengalami kekuarangan keuangan untuk mencocok tanam atau panen dalam proses bertani, sehingga pelaku weha rima dalam hal ini akan bergiliran bekerjasama (kooperatif) dalam menyelesaikan pekerjaan lahan atau lebih dikenal sistem bayar jasa karena tidak ada bentuk uang sebagi upah yang diperoleh. Singakatnya weha rima adalah sistem kerja sama dengan perjanjian harus dengan upah tenaga.

Aktifitas weha rima masyarakat desa Sondosia tempo dulu jika dianalisis dengan teori solidaritas sosial Emile Durkheim adalah tipe solidaritas sosial yang bersifat mekanik. Tipe solidaritas sosial mekanik adalah solidaritas yang didasarkan pada atas persamaan. Struktur sosial masyarakat yang berada pada tipe ini masih homogen dan tidak ada hubungan antara sistem yang satu dengan yang lain. Adapun pola kehidupan antar anggota masyarakat mempunyai kesadaran kolektif yang sangat tinggi. Pembagian kerja masyarakat yang menganut solidaritas mekanik belum begitu jelas dan tidak membutuhkan keahlian. Tipe masyarakat seperti ini biasanya terdapat di desa-desa yang masih memilihara kesadaran kolektif dan masyarakat desa adat. Kerja sama yang terjadi di antara mereka didasarkan pada hati nurani, kekeluargaan. Inilah yang Durkheim katakan sebagai pikiran kolektif atau penulis sebut sebagai nurani kolektif. Ciri lain dari masyarakat yang menganut solidaritas mekanik lebih bersifat komunal. Artinya Masyarakat desa Sondosia beberapa tahun 
yang lalu mayoritas sebagai petani dan jumlah penduduknya relatif sedikit dengan tingkat pendidikan yang masih rendah.

Pelaku yang melakukan weha rima dulu dilakukan oleh laki-laki dan perempuan, yang melakukan pekerjaan mereka sesuai dengan topoksi masing-masing berdasarkan jenis kelaminnya. Laki-laki dan perempuan ini bisa tergolong berumur tua atau dewasa bahkan remaja, karena budaya weha rima menjadi suatu wahana dimana muda-mudi bisa bertemu pasangan atau berjodoh. Namun sekarang sistem weha rima mengalami pergeseran. Weha rima di maasyarakat desa Sondosia hanya dilakukan oleh perempuan tua, orang-orang yang secara ekonomi mengalami kekurangan (miskin), dan hanya dilakukan dikalangan keluarga dekat atau tetangga.

$$
\text { Proses terjadinya pergeseran }
$$

solidaritas weha rima di masyarakat desa antara lain: (1) Kurangnya lahan pertanian di Desa Sondosia karena adanya pembangunan desa seperti: bangunan sekolah, rumah pribadi, rumah sakit, kampus dan kos-kos, (2) Tenaga manusia mulai digantikan oleh mesin pertanian, (3) Adanya pendatang yang mengerjakan proses pertanian di Desa Sondosia, (4) Jumlah pekerja (pelaku weha rima dan kelompok yang diupah) tidak sebanding dengan luas tanah yang digarap, (5) weha rima sebagai sistem bayar utang, dalam artian jasa dibayar jasa, (6) Weha rima tidak dapat membantu perekonomian keluarga, (7)
Masyarakat Desa Sondosia banyak bekerja di daerah luar seperti Sumbawa dan menjadi TKI.

Dalam teorinya Emile Durkheim tentang perubahan solidaritas sosial masyarakat, dari solidaritas sosial mekanik menuju solidaritas sosial organik. Solidaritas mekanik merupakan solidaritas sosial yang terbangun atas dasar kesadaran kolektif yang kuat dalam masyarakat dan memiiki keterikatan bersama sehingga mereka terlihat dalam aktifitas yang sama dan memiliki tanggung jawab yang sama. Solidaritas organik adalah hubungan masyarakat yang dilandaskan pada asa untung dan rugi serta lebih cenderung ke arah individualistik karena tingkat kesadarannya masih rendah, yang dimana solidaritas organik ini ada pada masyarakat modern (George Ritzet, 2011 : 9093).

Masyarakat Desa Sondosia dulu termasuk masyarakat yang solidaritas mekaniknya sangat tinggi, dalam artian di dalam kehidupan kemasyarakatan selalu menjunjung tinggi kerjasama atau gotong royong dalam menyelesaikan permasalah di masyarakat. Sama halnya budaya weharima yang menjadi kebiasaan masyarakat dapat bekerja sama dengan suka rela tanpa mendapatkan upah atau gaji. Akan tetapi kini yang terlihat dengan memulai memudarnya budaya weha rima, masyarakat Desa Sondosia sudah mengarah pada solidaritas semi organik, kenapa masyarakat masih menerapkan budaya 
weha rima walaupun sebagian besar sudah menggunakan modal dalam bekerja, sebagian kecil masih menggunakan sistem weha rima.

Teori fungsionalisme struktural yang dikatakann Talcott Parson bahwan terdapat empat imperatif fungsional yang diperlukan (atau menjadi ciri) seluruh sistem, antara lain: $\mathrm{A}=$ Adaptasi (adaptation), $\mathrm{G}=$ Pencapaian tujuan (Goal attainment), $\mathrm{I}=$ Integrasi (Integration), dan $\mathrm{L}=$ Latensi atau pemiliharaan pola (Latency). Adaptasi yakni sistem harus mengatasi kebutuhan situasional yang datang dari luar. Ia harus beradaptasi dengan lingkungan dan harus menyesuaikan lingkungan dengan kebutuhan-kebutuhannya. Pencapaian tujuan yakni sistem harus mendefinisikan dan mencapai tujuan-tujuan utamanya. Integrasi yakni sistem harus mengatur hubungan bagian-bagian yang menjadi komponennya. Ia pun harus mengatur hubungan antara tiga imperaktif fungsional tersebut (A, G, L). Pemeliharaan pola (latensi) yakni sistem harus melengkapi, memelihara dan memperbaharui motivasi individu dan pola-pola budaya yang menciptakan dan mempertahankan motivasi tersebut (George Ritzet dan Douglas J.Goodman, 2011 : 257).

Pada budaya weha rima terealisasi kini sesuai dengan kebutuhan dana keadaan para masyarakat yang menjadi pelaku weha rima, ini dikarenakan dari hasil penelitian tentang faktor-faktor yang mempengaruhi budaya weharima, mulai memudarnya kebudayaan weha rima dikarenakan tidak sesuainya sistem weha rima dengan kebutuhan ekonomi keluarga, sehingga dalam pekerjaan bercocok tanam maka adanya buruh tani yang digaji dengan buruh tani yang menjadi pelaku weha rima.

Pencapaian tujuan dalam budaya weha rima terdapat beberapa komponen, antara lain: melestarikan budaya nenek moyang weha rima, menjaga kerjasa sama atau gotong royong di masyarakat, sistem bayar jasa. Pelaku weha rima hingga kini terdapat $25 \%$ dari jumlah pekerja yang melaksanakan pekerjaan persawahan atau berladang, dan 75 \% tidak melaksanakan sistem weha rima, dalam artian sebagai pekerja atau buruh tani yang diupah atau mendapatkan gaji.

Integrasi dalam budaya weha rima akan terjaga bila pemerintah desa, pelaku weha rima dan pemilik tanah sama-sama berkomitmen membuat kesepakatan bersama atau Peraturan Desa (Perdes) dengan isi melestarikan budaya weha rima, dalam setiap pekerjaan persawahan dan berladang mesti adanya sistem weha rima.

Pemeliharaan pola budaya weha rima kini masih ada terlaksana walaupun sudah sedikit masyarakat yang melakoninya. Pemilik tanah kadang mselakukan perjanjian dengan buruh tani pada awalnya tidak menentukan bahwa buruh tani tersebut akan diberikan upah atau akan melakukan weharima, sehingga setelah pelaksanaan weha rima sudah selesai 
dikerjakan, buruh tani akan meminta upah sebagai pengganti tenaga yang telah dikeluarkan akan tetapi pemilik tanah mengulur-ngulur pemberian gaji sehingga pada akhirnya masuk pada sistem weha rima karena enggannya pemilik tanah memberikan upah.

Proses perubahan sosial weha rima dikalangan masyarakat Desa Sondosia dilatarbelakangi oleh perubahan tipe masyarakat dari solidaritas mekanik ke solidaritas organik. Masyarakat Desa Sondosia dimana sistem sosial masyarakat tidak lagi bersifat homogen tapi heterogen. Adapun masyarakat dalam tipe solidaritas organik merupakan sistem terpadu dalam kerangka keragaman. Keragaman tersebut berfungsi untuk kepentingan keseluruhan sistem-sistem. Setiap sistem mempunyai fungsinya masing-masing dan tidak dapat di ambil alih oleh sistem yang lain. Masyarakat dalam tipe ini mengalami saling ketergantungan yang besar sehingga menuntut adanya kerja sama. Pembagian kerja masyarakat yang berada pada tipe ini telah mengalami spesialisasi. Kerja sama diantara mereka terjadi karena didasarkan pada hukum akal, dan atas dasar paksaan. Tipe masyarakat tipe ini dapat kita temukan pada masyarakat kota yang dimana tingkat kompleksitas masalahnya sangat beragam yang dapat dibedakan antara solidaritas mekanik dan solidaritas organik
Mentalitas masyarakat pada tipe ini lebih bersifat individual. Di dalam bukunya yang di Durkheim (Maliki. 2010) mengatakan"memang sangat berbeda, struktur masyarakat solidaritas organik sangat kuat. Mereka di bentuk bukan atas dasar pengulangulangan hal-hal yang sama segmen yang homogen, melaingkan oleh sistem organ yang berbeda yang masing-masing memiliki peran tertentu, yang masing-masing membentuk bagian-bagian yang berbeda. Bukan hanya elemen-elemen sosial itu karakternya tidak sama. Akibatnya, individu dikelompokkan, bukan lagi atas dasar hubungan-hubungan keturunan, akan tetapi atas dasar sifat-sifat aktifitas sosial tertentu, tempat dimana manusia menghimpun diri. Dasar lingkungan dimana mereka hidup, bukan lagi lingkungan atas dasar kelahiran, akan tetapi lingkungan akupasional". Artinya Solidaritas organik di mana masyarakatnya di ikat oleh kemampuan dan ia memerankan diri berdasarkan kemampuan tersebut.

\section{Kesimpulan}

1. Budaya weha rima merupakan budaya khas masyarakat Desa Sondosia yang menggunakan sistem tolong menolong dengan sistem tenaga.

2. Faktor-faktor yang mempengaruhi mulai memudarnya budaya weha rima, baik sebagai faktor pendukung atau faktor pemicu kurangnya pelaku atau 
pelaksanaan weha rima, antara lain: (1) Kurangnya lahan pertanian di Desa Sondosia karena adanya pembangunan desa seperti: bangunan sekolah, rumah pribadi, rumah sakit, kampus dan kos-kos, (2) Tenaga manusia mulai digantikan oleh mesin pertanian, (3) Adanya pendatang yang mengerjakan proses pertanian di Desa Sondosia, (4) Jumlah pekerja (pelaku weha rima dan kelompok yang diupah) tidak sebanding dengan luas tanah yang digarap, (5) weha rima sebagai sistem bayar utang, dalam artian jasa dibayar jasa, (6) Weha rima tidak dapat membantu perekonomian keluarga, (7) Masyarakat Desa Sondosia banyak bekerja di daerah luar seperti Sumbawa dan menjadi TKI.

\section{Daftar Pustaka}

Arikunto, Suharsimi, 2006, Prosedur Penelitian Suatu Pendekatan Praktik, Jakarta : Rineka Cipta.

Darmadi. Hamid, 2013, Dimensi-Dimensi Metode Penelitian Pendidikan dan Sosial Konsep Dasar dan Implementasi, Bandung: Alfabeta.

Jhonson. Paul. Doyle, 1990, Teori Sosiologi Klasik dan Modern, Jakarta, PT. Gramedia Pustaka Utama.

Husain Assadi, 2008, Masyarakat Petani, (Online) http://husainassadi.blogspot.com/200 8/04/masyarakat-petani.html, (Akses, 19 Agustus, 2018)

Mahyuni, 2009, Bahasa Perubahan Sosial dan Kearifan Lokal, Universitas Negeri Mataran (UNRAM).

Moleong. Lexi J., 2010, Metode Penelitian Kualitatif, Bandung: PT.Remaja Rosdakarya.

Mustain, 2007, Petani Vs Negara : Gerakan Sosial Petani Melawan Hegemoni Negara, Jakarta : PT. Ar-Ruzz Madia.

Slamet. Yulius, 2011, Metode Penelitian Sosial, Surakarta : Lembaga Pengembangan Pendidikan (LPP) dan UPT Penerbitan dan Percetakan UNS (UNS Press)

Soekanto. Soejono, 2006, Sosiologi Suatu Pengantar, jakarta : PT. Raja Grafindo Persada.

Sugiyono, 2008, Metode Penelitian Kuantitatif dan Kualitatif, Bandung : Alfabeta

---------, 2010, Metode Penelitian Kuantitatif, Kualitatif, dan $R \& D-$ Cetakan Ke-9, Bandung: Alfabeta.

Suprapto, 2013, Metodologi Penelitian Ilmu Pendidikan dan Ilmu-Ilmu Pengetahuan Sosial; Penelitian Kuantitatif dan Kualitatif Dilengkapi dengan Teknik Pengolahan Data dan Tabel Statistik, Yogyakarta: CAPS (Center for Academic Publishing Service).

Ritzet. George, 2011, Teori Sosiologi, Kreasi Wacana.

Ritzer, George. dan Douglas J. Gooman, 2004, Teori Sosiologi Modern. Jakarta: Prenada Media.

Tim Prima Peta, 2006, Kamus Ilmiah Populer, Surabaya : PT. Gita Media Press. 